\title{
Population Structure and Curative Uses of Invasive Plants in and around the Protected Forests of Bangladesh: A Means of Utilization of Potential Invasive Species
}

\author{
Md. Habibur Rahman and Bishwajit Roy \\ Bangladesh Institute of Social Research (BISR), Hasina De Palace, House No. 6/14, Block No. A, Lalmatia, Dhaka 1207, Bangladesh \\ Correspondence should be addressed to Md. Habibur Rahman; habibmdr@gmail.com
}

Received 26 June 2013; Accepted 22 December 2013; Published 12 February 2014

Academic Editor: Henry M. Page

Copyright (C) 2014 Md. H. Rahman and B. Roy. This is an open access article distributed under the Creative Commons Attribution License, which permits unrestricted use, distribution, and reproduction in any medium, provided the original work is properly cited.

\begin{abstract}
Invasive plants were planted in Bangladesh to improve the stand stock quickly and meet the country's rapidly growing demand for timber. Although invasive species have negative impacts on local ecosystems, but some species are useful too. Therefore, the present study was conducted in and around two protected forests of Bangladesh to assess the status, species diversity, and curative uses of invasive plants. A total of 60 sample plots were surveyed from 5 habitat types, for example, forest, roadside, homestead, fallow land, and others. Plants uses data were collected through interviews and focus group discussions. Study recorded 43 invasive medicinal plant species belonging to 28 families, of which Asteraceae constituted the highest family importance value (21.9). Among the habitat types, fallow land (32 species) and roadside ( 29 species) possess the highest number of species. Based on people's perceptions, plants were categorized into three level of invasion: low (11 species), moderate (19 species), and high (13 species). The use of aerial plant parts was higher $(68 \%)$ than the whole plant (17\%). Consensus of local community's (ICF) was high in managing gastrointestinal (0.65) followed by respiratory (0.60) diseases. A number of biological diversity indices were applied to quantify definite diversity. Therefore, a national programme must be initiated to increased invasive plant inventory, monitoring, and research on distinguishing the harmful from the harmless species and identifying the potential uses of invasive species.
\end{abstract}

\section{Introduction}

The practices of plant-based traditional medicine are based on hundreds of years of belief and observations, which predate the development and spread of modern medicine $[1,2]$ and this knowledge has been passed on orally from generation to generation without any written document [3]. During the last few decades, the study of medicinal plants and their indigenous use in the world has been increasing and an interesting issue for the researcher and natural resource manager $[4,5]$. Such type of study is important for the conservation and utilization of biological resources and found to be one of the reliable approaches to drug discovery $[4,6]$. A total of 70,000 plant species have been used for medicinal purposes in the world [7] and among 6,500 species found in Asia [8]. In Bangladesh, at least 500 species of plants is commonly used as medicinal purposes [9].
The World Health Organization estimates that, in some Asian and African countries, $80 \%$ of the population depend on traditional medicines for their primary health care [10] and over $50 \%$ of the population in North America, Europe, and other industrialized countries use plants and plant extracts for their medicinal needs [11].

"An invasive (some termed as exotic/alien) species that becomes established in natural or seminatural ecosystems or habitat is an agent of change and threatens native biological diversity is termed as invasive species" $[12,13]$ and SCBD [14] defined invasive plants, "as the plant species introduced deliberately or unintentionally outside their natural habitats, where they have the ability to establish themselves, invade, out-compete natives, and take over the new environment". After habitat destruction and fragmentation, invasive species are known as the most important cause of biodiversity loss $[15,16]$ and cause considerable damage to the natural 
ecosystems, also cause significant damage to human health and the economy [17-20]. Although indigenous knowledge on medicinal uses of native plants is well documented [21], very little is known about the medicinal uses of invasive plants [22].

Bangladesh, a small country, is endowed with a surprisingly rich diversity of plant species, estimated to be about 6000 including bryophytes, pteridophytes, gymnosperms and angiosperms [23]. A total of $77 \%$ of the country's population live in rural areas and almost $80 \%$ of them are dependent on medicinal plants for primary health care [24]. Bangladesh has more than 300 invasive species which grow either wildly or are widely cultivated throughout the country [25]. The plantation of invasive species as introduced in Bangladesh during the British colonial period from the late 1880s to early 1890s for their aesthetic value and to meet the country's rapidly growing demand for timber (e.g., Tectona grandis, Paraserianthes falcataria, Albizia saman, Xylia dolabriformis, and Swietenia macrophyllaetc). Later, in the 20th century this trend continued, and some Australian species (Eucalyptus camaldulensis, Eucalyptus grandis, Leucaena leucocephala, Acacia mangium, Acacia auriculiformis, Pinus oocarpa, and Pinus caribaea) are now dominating in all the plantation programmes and growing well in all sorts of degraded land $[9,23,25,26]$.

Invasive species in Bangladesh are dominating due to their luxuriant growth and suppress the growth of other native species and ecosystems. This results in a loss of native floral diversity of the country and is becoming a major concern among conservationists, ecologists, foresters, policy makers, and scientists for their severe biological, ecological, and socioeconomic impacts. But limited research works have been conducted on invasive plant species in forest ecosystem of Bangladesh [22, 25-39]. It is true that invasive species have negative impacts on local ecosystems [40], but not all of them are harmful. Many invasive species support our farming and forestry systems in a big way, while some invasive plants have medicinal properties, therefore, it is essential to document the curative uses of other invasive plants [22].

About 34 protected areas have been declared in Bangladesh. People living in and around the protected areas of Bangladesh rely extensively on natural resources to meet their subsistence requirements, a considerable portion of which includes medicines. This study was undertaken in two protected forests, namely, Khadimnagar National Park (KNP) and Rema-Kalenga Wildlife Sanctuary (RKWS), located in the northeastern region of Bangladesh, to document the status, diversity, and uses of invasive plant as medicinal plants. In Bangladesh various research works have been done to identify the invasive species, their extent, impact on ecosystem, and biodiversity, but no study was so far carried out solely on the population status of invasive plants species which are used as medicinal plants. The present study is aimed to assess the diversity and traditional uses of invasive plants for curative purposes. This paper further attempted to explore the used pattern of these invasive plants for health care practices through indigenous knowledge in and around KNP and RKWS of northeastern Bangladesh.

\section{Materials and Methods}

2.1. Case Study Sites. In the study, KNP and RKWS were selected purposively considering their unique geophysical features, richness in biological diversity and households' dependency on forest resources. KNP is located at North Sylhet Range-1 and RKWS is located at Habigonj-2 Range in Sylhet Forest Division under tropical evergreen and semievergreen biogeographic zone. Geographically KNP lies between $24^{\circ} 56^{\prime}-24^{\circ} 58^{\prime} \mathrm{N}$ and $91^{\circ} 55^{\prime}-91^{\circ} 59^{\prime} \mathrm{E}$. However, RKWS lies between $24^{\circ} 06^{\prime}-24^{\circ} 14^{\prime} \mathrm{N}$ and $91^{\circ} 34^{\prime}-91^{\circ} 41^{\prime} \mathrm{E}$ (Figure 1) [41]. Total area of KNP and RKWS are 679 ha and 1995 ha, respectively. The hills of these areas are generally low and gently sloping. Soil ranges from clay loams to pale brown (acidic) clay loams on the hills. RKWS represents a total of 606 plant species (242 herbs, 120 shrubs, 147 trees, and 97 climbers), among them 82 have been identified as medicinal plants [42]. KNP operates on the principle of production forestry; for example, the forest was periodically clear felled and subsequently planted with valuable timber trees and other plants, but no actual floral survey information on plants is available [43]. These areas enjoy a moist tropical monsoon climate characterized by a period of high rainfall from April to September and a five-month relatively dry period from November to March. The tropical monsoon climate prevails in the area with average maximum temperature of $30.7^{\circ} \mathrm{C}$ and average minimum temperature of $18.9^{\circ} \mathrm{C}$. The average annual rainfall is $3931 \mathrm{~mm}$, most of which falls between June and September [22].

2.2. Research Methods. The present study was conducted in two phases, namely, respondent survey at the first phase and plot survey from different habitats at the second phase in the study areas. Equal numbers of respondents and sample plots were selected from two study areas. The structure of any plant community cannot be studied by observing each and every individual of plant species growing in a habitat. Therefore, rough estimates of species content in a habitat can be made by observing the plant species at different places or sample areas, in the habitat [44]. Therefore, sample plots in the study areas were selected from 5 different habitats, namely, forest, roadside, homestead (surrounding forest dwellers house), fallow land, and others (ponds, canals, water logged areas, and agricultural land).

2.2.1. Data Collection from Respondents. Interviews were conducted targeting primarily age old or local experienced persons (predominantly male (69\%) and usually aged between 40 and 90 years with an average of 55 years). Total 110 respondents, 55 from each study area, were selected for interview. At the family level, informal meetings were held in the interviewee's home using the native language (Bangla), sometimes with the participation of more than one respondent together, everyone being selected randomly. The selection of respondents was purposive; we considered those who have medicinal knowledge and practices. A semistructured questionnaire and checklist for focus group discussions were arranged to collect data on curative uses of invasive 


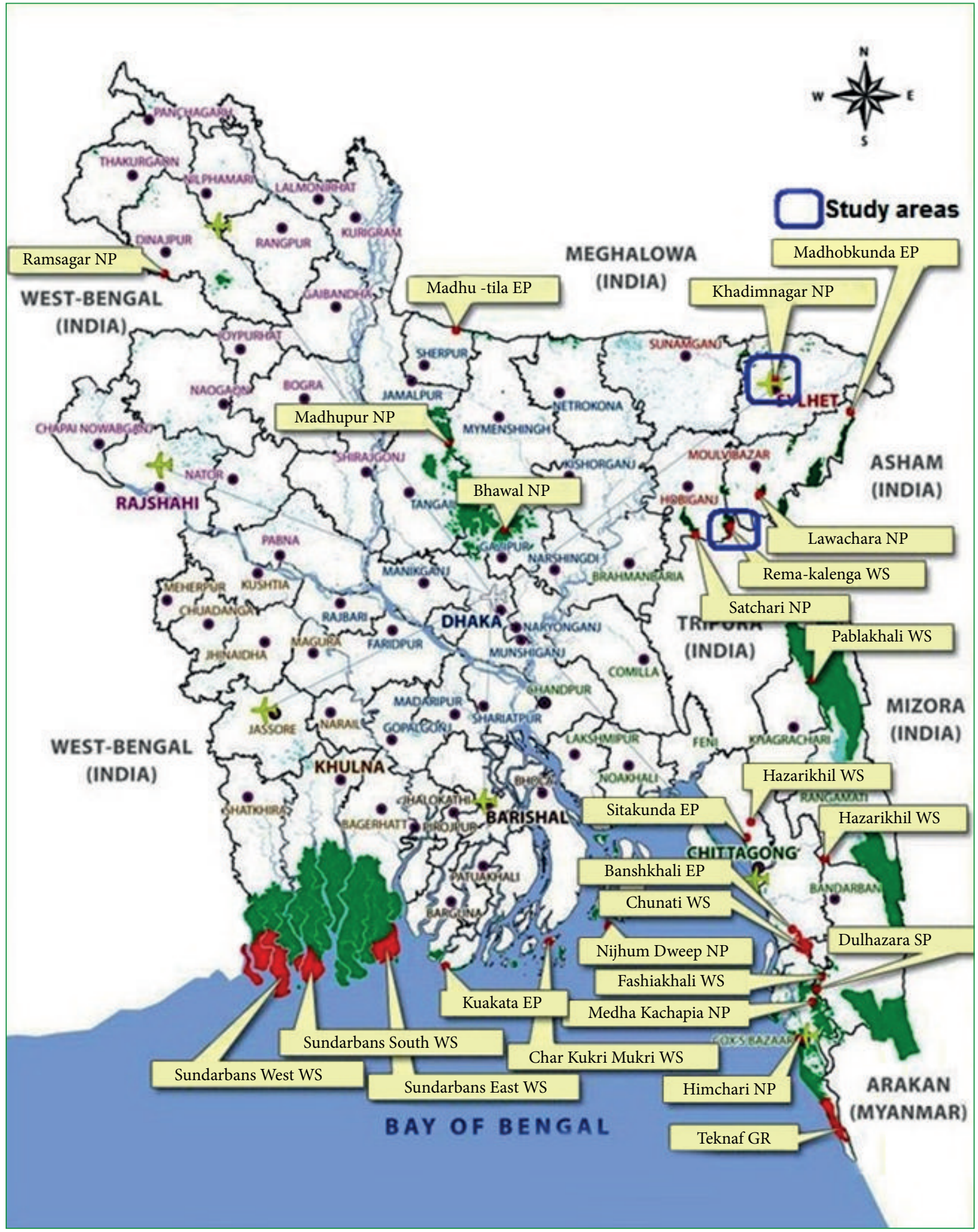

FIGURE 1: Location map of the study areas.

plant species. Respondents were also asked which plant parts were mostly used for which ailments and how they prepare medicine. Furthermore, degrees of invasiveness of invasive plants were also measured through respondents' opinion. A list of 43 invasive medicinal plants of the study area was provided to each respondent and asked to sort these in 5 preselected categories, namely, naturalized, introduced, low level of invasive, moderately invasive, and highly invasive. Thus opinions regarding the degrees of invasiveness were taken from 110 respondents. Finally, the category that belongs 
to the highest percentage for each invasive medicinal plant was set as degree of invasiveness of that particular individual. Detailed information was noted during interviews and information gaps were amended through additional visits and cross-checking. Data collected from the respondents were cross-checked through interviewing 5 kabiraj (local traditional healers living and working in the study areas who received training and practiced on herbal medicine).

2.2.2. Data Collection from Sample Plot. A stratified random quadrate method was used to determine the invasive medicinal plants diversity. A total of 60 samples plots (30 plots from each study area and 6 plots from each habitat) were randomly selected for the study. Circular plots of $10 \mathrm{~m}$ radius were used as sample plot for tree species and $2 \mathrm{~m}$ radius for herbs, shrubs, climbers, and grasses [45]. Circular plot was used as it minimizes the edge effect of taking sample plots. Total number of species and their individual name were collected for invasive trees, shrubs, herbs, climbers, and grasses. During the field visit, invasive species were identified using $[22,25,30,32,34]$. Bangla names have been well documented by Dey [46].

2.2.3. Data Analysis. Based on the information about the species, their parts used, and ailments treated, we calculated the informants' consensus factor (ICF) for each disease category and disease. ICF values were determined following Trotter and Logan [65] to evaluate local peoples' consensus on managing human ailments. The formula used to calculate these values was:

$$
\mathrm{ICF}=\frac{n u c-n s}{n u c-1},
$$

where nuc is the number of use citations for a specific ailment and $n s$ is the number of species used to treat the ailment.

The ICF is an indicative value of how consistent the informants are and the extent to which they agree about the use of plant species for treatment of a given ailment or ailment category [66]. ICF value ranges from 0 to 1 . A high value (close to 1 ) indicates that the species are used by a large proportion of the informants indicating a consistent use of the medicinal resources.

During the present study, nine diversity and richness indices were analyzed to get a clear picture of regeneration diversity of the study areas, which was listed below. [67]:

Species diversity index was calculated according to Odum

$$
\mathrm{SDI}=\frac{S}{N}
$$

Species richness index was measured by Margalef [68]:

$$
R=\frac{(S-1)}{\operatorname{Ln}(N)}
$$

Shannon-Wiener diversity index was calculated according to Michael [69]:

$$
H=-\sum P i \operatorname{Ln} P i
$$

Shannon's maximum diversity index was calculated according to Kent and Coker [70]:

$$
H_{\max }=\operatorname{Ln}(S) \text {. }
$$

Shannon's equitability index according to Kent and Coker [70]:

$$
\mathrm{EH}=\frac{H}{H_{\max }} .
$$
[71]:

Species evenness index was estimated following Pielou

$$
E=\frac{H}{\log (S)}
$$
[72]:

Simpson index was estimated according to Magurran

$$
D=\sum P i^{2}
$$

As biodiversity increases, the Simpson index decreases. Therefore, to get a clear picture of species dominance, the following formula was used:

$$
D^{\prime}=1-D
$$

Berger-Parker dominance index was calculated according to May [73]:

$$
d=\frac{N_{\max }}{N}
$$

where $S$ is the total number of species; $N$ is the total number of individuals of all the species; $P i$ is the number of individuals of one species/total number of individuals in the samples.

Family importance value (FIV) index according to the formulae of Mori et al. [74]:

Family relative density (\%)

$$
=\frac{\text { Number of individuals in a family }}{\text { Total number of individuals }} \times 100
$$

Family relative diversity (\%)

$$
=\frac{\text { Number of species in a family }}{\text { Total number of species }} \times 100 .
$$

FIV is the sum of family relative diversity and relative density.

\section{Results and Discussion}

3.1. Invasive Medicinal Plant Composition in and around KNP and RKWS. During field investigations, a total of 43 invasive medicinal plant species belonging to 28 families were recorded, which is used for medicinal purposes by the local communities living in and around KNP and RKWS. Scientific name, local name, family, habit, main sources, parts used, ailments, and suspected origin of these species are enlisted in Table 1. Most of them belong to Asteraceae ( 4 species) and 


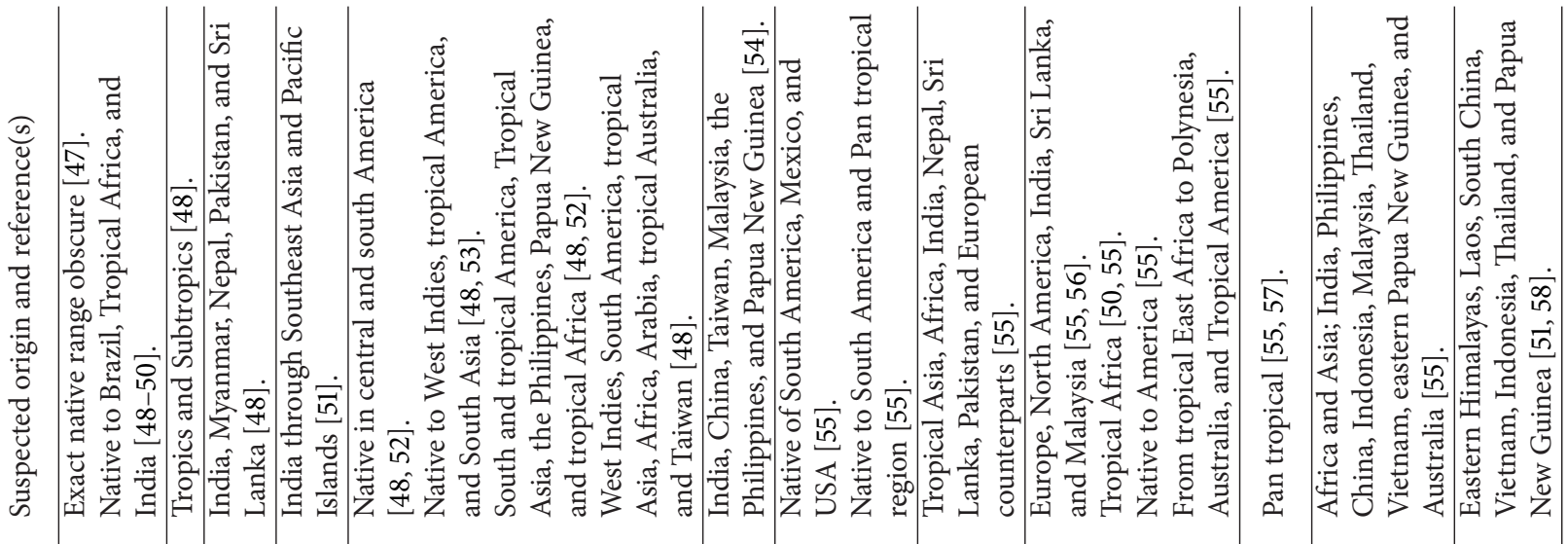

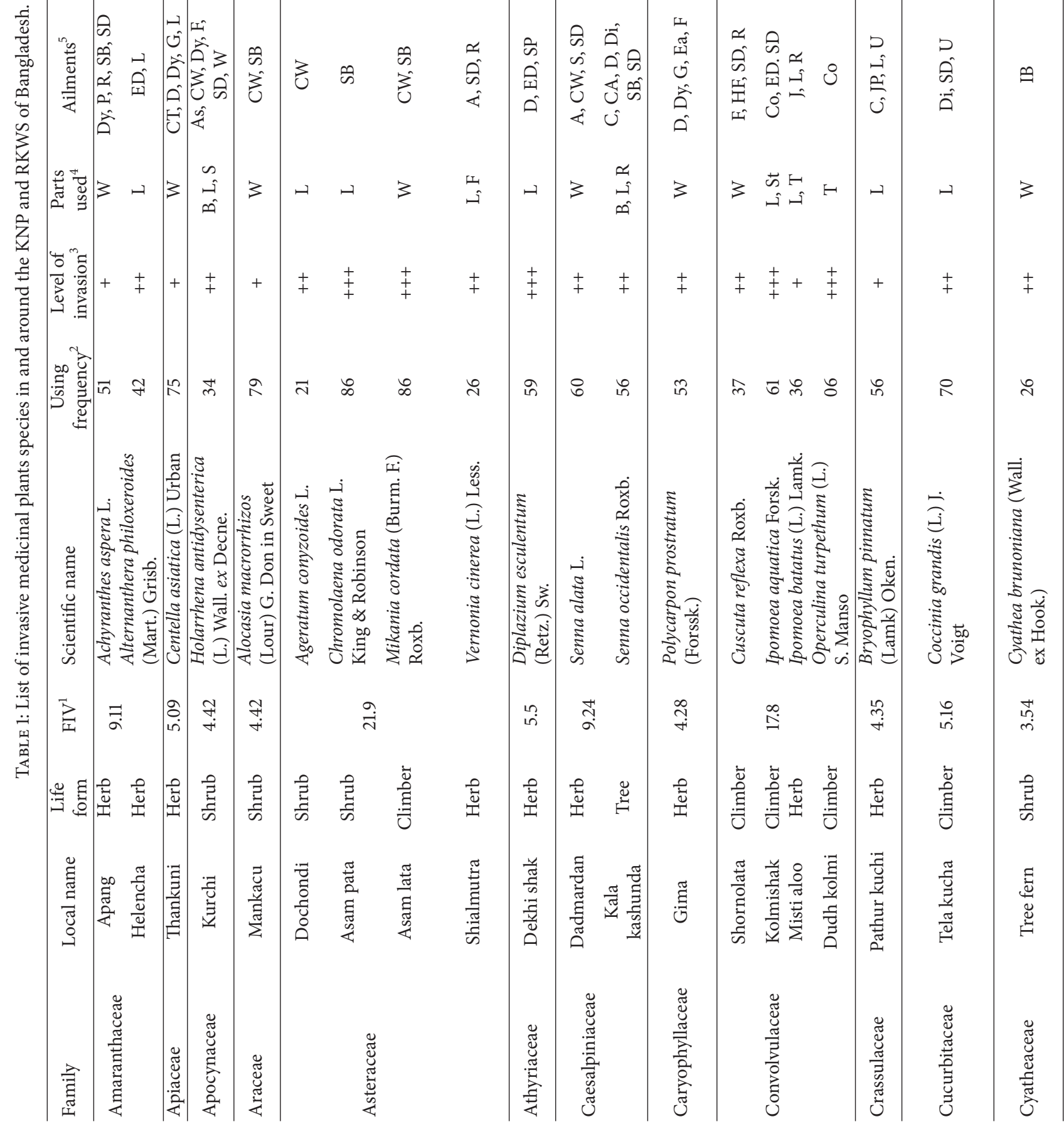




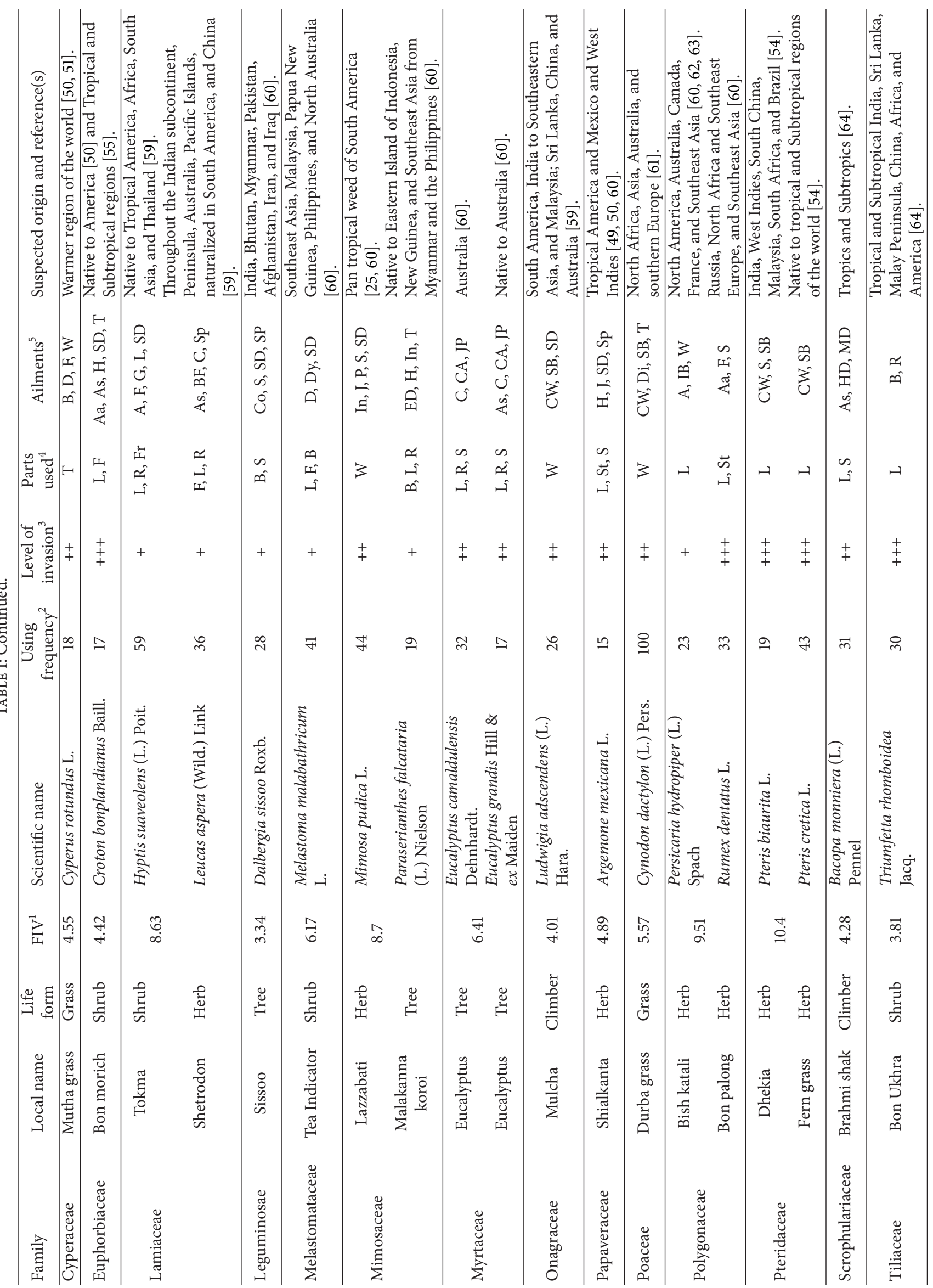




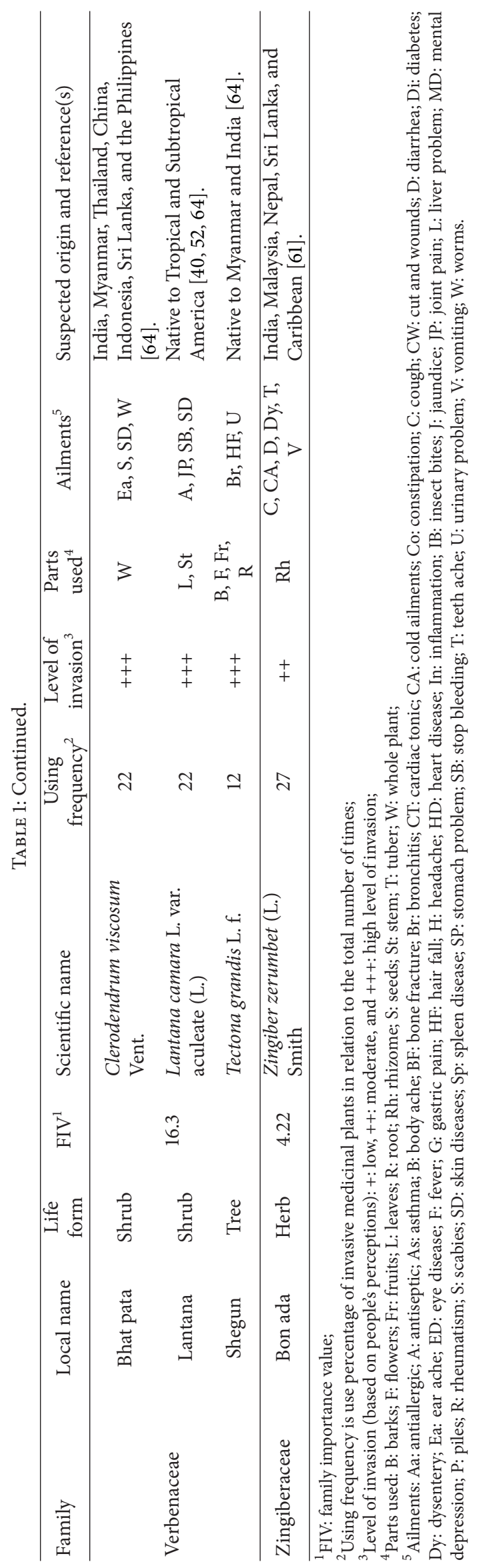




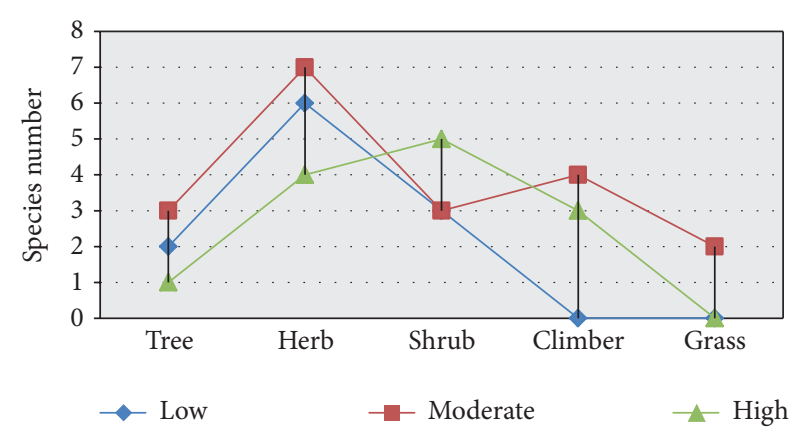

FIGURE 2: Level of invasiveness and habit wise species distribution.

Convolvulaceae (4 species) family followed by Verbenaceae (3 species), Amaranthaceae, Caesalpiniaceae, Lamiaceae, Mimosaceae, Myrtaceae, Polygonaceae, and Pteridaceae (2 species each) which were found to have frequent use. Each single species was found from 19 other families. Furthermore, Table 1 also shows the family importance value (FIV) index of the recorded species. The individuals number of species and FIV were greatest for the recorded family of Asteraceae (individuals 186, FIV 21.9) followed by Convolvulaceae (individuals 126, FIV 17.8), Verbenaceae (individuals 138, FIV 16.3), respectively. Other studies from across the country in the forested areas for example, Khan et al. [21], Khan et al. [22], Rahman et al. [75], Rahman and Fardusi [76], Rahman et al. [77-79], Chowdhury and Koike [80, 81], Rana et al. [82], Rana et al. [83], Mukul et al. [84], and Miah and Chowdhury [85] recorded that the species under the Apocynaceae, Araceae, Asteraceae, Combretaceae, Compositae, Convolvulaceae, Euphorbiaceae, Fabaceae, Liliaceae, Lamiaceae, Leguminosae, Papaveraceae, Rubiaceae, Rutaceae, Solanaceae, Sterculiaceae, and Verbenaceae families are frequently used as medicinal plants in Bangladesh.

The present study also explored the level of invasion (based on peoples' perception) of the invasive medicinal plants. Among the recorded species highest number of species falls under the category moderately invasive (species that are spreading but still occur at moderate densities and are considered to have some immediate problem) (19 species, $44.19 \%$ ) followed by highly invasive (species that have become dominant or codominant in the invaded region and are considered a threat to the native flora and ecosystem) (13 species, $30.23 \%)$. Whereas lowest number of species belongs to the category low level of invasive (11 species, 25.58\%) (species that has self-sustaining and spreading capability with no human support but not necessarily hamper other plant's growth). Among the species, 1 tree, 4 herbs, 5 shrubs, and 3 climbers species fall under the category of highly invasive; 3 trees, 7 herbs, 3 shrubs, 4 climber, and 2 grasses species are under moderately invasive category; and 2 trees, 6 herbs, and 3 shrubs species fall under the category of low level of invasive (Figure 2).

Majority of the invasive plants used by the local inhabitants as medicinal plants were herbs (17 species, 39.53\%) followed by shrubs (11 species, $25.58 \%)$, climbers (7 species, $16.28 \%$ ), trees (6 species, 13.95\%), and grasses ( 2 species,

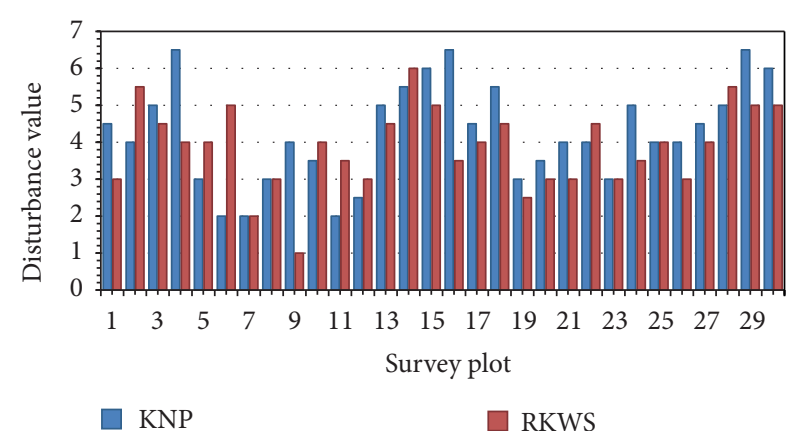

FIGURE 3: Relationship between disturbance value and survey plot in different habitats of KNP and RKWS of Bangladesh.

4.65\%) in the study areas. In case of level of invasiveness, $16.67 \%$ trees are highly invasive, $50 \%$ are moderately invasive, and $33.33 \%$ are low level of invasive; among the species $23.53 \%$ herbs are highly invasive, $41.18 \%$ are moderately invasive, and $35.29 \%$ are low level of invasive; $45.45 \%$ shrubs are highly invasive, $27.27 \%$ are both moderately, and low level of invasive; and $42.86 \%$ climbers are highly invasive and $57.14 \%$ are moderately invasive, whereas $100 \%$ grasses moderately invasive.

Results also revealed that species frequency of occurrences varied according to five different habitats in the study areas. Among these 5 habitats, diversity of recorded invasive medicinal plant species was highest in fallowland (32 species) followed by roadside (29 species), forest (27 species), homestead (24 species), and others sites (17 species) accordingly. Results of this study also indicate that diversity of herbs (14 species) was highest in the fallow land followed by roadside (12 species), homestead (11 species), forest (9 species) and others (7 species); shrubs was highest in both fallow land and roadside (9 species), followed by forest (8 species), homestead (6 species), and others (5 species). Climbers was highest in the fallow land and forest (each containing 4 species); and in roadside, homestead, and others habitats containing 3 species each. However, the number of trees ( 5 species) was highest in the forest followed by roadside (4 species).

Various disturbances like pest and disease attack, drought, cattle browsing, human disturbance, poor drainage, low moisture, and nutrient deficiency were observed during the field survey and were scored according to their intensity. Figure 3 shows the disturbance values according to the habitats; for example, first six plots were in fallow land, next six plots were in forest, plots 13 to 18 were in roadside, plots 19 to 24 were in homestead, and 25 to 30 were in others for the both study areas. It was observed that highest disturbance score was recorded from the road side, fallow land, and others habitat in both the study areas. It is considered that invasive species can only spread into natural vegetation because of disturbance [26] thereafter this is true for present study findings. Invasive species shows three types of negative impacts with their associated species and ecosystem these are competing with indigenous plants for light, nutrients, and moisture; impede natural regeneration; and replace 
indigenous plant communities [30]. The spread of invasive species is now recognized as one of the greatest threats to the ecological and economic wellbeing of the planet [86].

3.2. Notes on Plant Utilization. The survey revealed that forest dependent community used different parts of invasive medicinal plants in their health care practices. The uses of invasive medicinal plants mentioned by the respondents are presented in Table 1. Most plant parts are consumed after processing such as macerating; squeezing; grinding; blending; soaking or boiling in water, milk, or mustard oil; rubbing; or burning. Some are taken raw and some are applied externally. Both the aerial and below ground plant parts are used in health care in the study area-aerial parts $68 \%$, whole plant $17 \%$, and the below ground parts $15 \%$. In some cases different parts were used for treating different ailments; in other cases, similar or different parts of more than one plant were mixed together to treat a single ailment. Leaves were the most widely used parts accounting for $37 \%$ of the reported medicinal plants, followed by whole plant (17\%), root $(10 \%)$, bark $(9 \%)$, seeds $(8 \%)$, flowers $(7 \%)$, stem and tuber of each (4\%), fruits (3\%), and rhizome (1\%) (Figure 4).

A total of 38 different ailments were found to be treated with the medicinal plants recorded. All the ailments were grouped into predefined ethnobotany categories [87], with the addition of a few others, forming nine ailment categories: ache, dermatological, faunal bite, gastrointestinal, general health, jaundice, mental, respiratory, and urinary (Table 2). Some were taken raw and some after cooking. Some were applied externally to different body parts for cuts and wounds, scabies, pain, or skin diseases. Water was mostly used to dilute the extract from the fresh plant parts. Sometimes, mustard, oil, salt, sugar, and honey were added to plant parts to make them more palatable.

\subsection{Consensus on Managing Ailments among Informants.} The ICF (informant consensus factor) values for the ailment categories (Table 2) indicate the degree of shared knowledge among the respondents for the treatment of ailments by medicinal plants. The greater the consensus factor the more likely that the remedy is biologically efficacious [88]. Among the ailment categories used in the present study, gastrointestinal problems scored the highest ICF value 0.65 . 30\% of the total species were in use for the treatment of this category that includes gastric pain, liver problem, stomach problem, and vomiting. Respiratory (asthma and cough) problems were second ICF value of 0.60 with the involvement of 11 species $(25.60 \%)$ and general health category (diarrhea, dysentery, fever, stop bleeding, cold ailments, etc.) ranked third with an ICF value of 0.53 ; although the highest number of species ( 47 species), representing $105 \%$ of the total, were reported to be used in its treatment. A high consensus of sexual problems (1.00) and respiratory problems (0.56) were found at forested and nonforested regions of Bangladesh [82]; ICF value 0.92 for the treatment of jaundice was found among the Malasars community of India [89]; eczema was found highest (0.58) at Bale Mountains National Park, Southeastern Ethiopia [90], while the consensus for gastrointestinal illnesses was highest

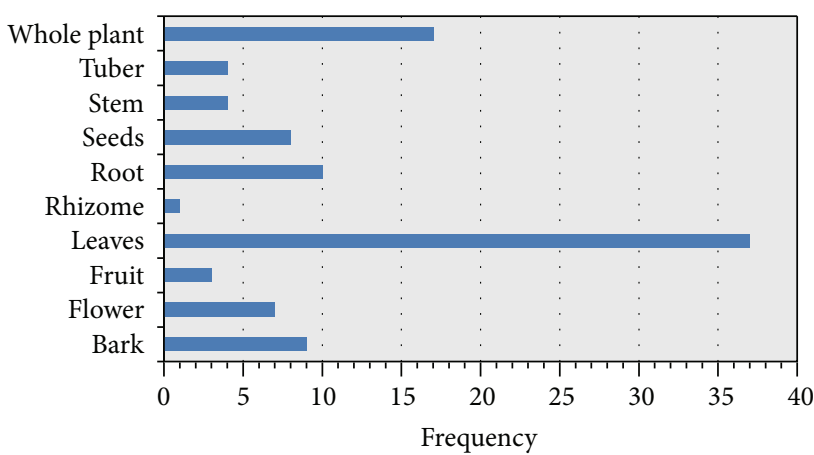

FIGURE 4: Traditional uses of invasive medicinal plant parts in the study areas.

(0.68) among the Nahua community of Mexico [88]. There was no consensus value (0.00) among the informants in the study area for the inflammation, worms, vomiting, bronchitis, cardiac tonic, and mental depression; conceivably this was because of the easily accessible allopathic medicines available in the local pharmaceuticals shops and community hospitals in both study areas. The respondents can buy pharmaceutical medicines to provide quick pain relief cheaply, thus reducing the use of traditional remedies.

3.4. Invasive Medicinal Plants Diversity Indices. Table 3 shows the different biological diversity indices for invasive medicinal plants species status in the study areas of 60 surveyed plots. Shannon-Wiener diversity index was highest for herbs (2.75) followed by shrubs (2.40), climbers (1.91), trees (1.76), and grasses (0.68), while Shannon's maximum diversity index was highest for herbs (2.77) followed by shrubs (2.48). Shannon's equitability index was highest for herbs (0.99) followed by climbers, grasses, and trees (0.98) each, respectively. Species diversity index was calculated highest for trees $(0.06)$ followed by herbs, shrubs, and climbers jointly $(0.03)$, respectively. The value of species richness index was estimated higher for herbs (2.35); similarly evenness index was highest for herbs (2.29). However, Simpson index was found higher for grasses (0.5) followed by trees (0.18). The calculated value of evenness index that are almost similar for each category and index of dominance of the study areas revealed that the total number of individuals are more evenly distributed among all species present at the two study sites. Rahman et al. [91], Rahman et al. [92], and Top et al. [93] believed that the higher the value of diversity, the greater the stability of community will be.

3.5. Berger-Parker Dominance Index. It is simple measure of the numerical importance of the most abundant species. This index indicates that an increase in the value of the index accompanies an increase in diversity and a reduction in dominance. We calculated the Berger-Parker dominance index of the invasive medicinal plants species of the study areas. In case of herbs the dominant species is Pteris cretica (0.09), Chromolaena odorata (0.13), Mikania cordata (0.21), 
TABLE 2: Ailment categories and degree of local communities' consensus on managing ailments in and around KNP and RKWS, in Bangladesh.

\begin{tabular}{|c|c|c|c|c|}
\hline Ailments category & Biomedical term & ${ }^{\mathrm{a}}$ Number of plants species & ${ }^{\mathrm{a}}$ Percentage of total species & ${ }^{\mathrm{b}} \mathrm{ICF}$ \\
\hline \multirow[t]{9}{*}{ Ache } & & & 53.50 & 0.52 \\
\hline & Body ache & 2 & & 0.28 \\
\hline & Bone fracture & 1 & & 0.39 \\
\hline & Ear ache & 2 & & 0.43 \\
\hline & Headache & 3 & & 0.50 \\
\hline & Inflammation & 2 & & 0.00 \\
\hline & Joint pain & 4 & & 0.63 \\
\hline & Rheumatism & 5 & & 0.43 \\
\hline & Teeth ache & 4 & & 0.40 \\
\hline \multirow[t]{6}{*}{ Dermatological } & & & 90.70 & 0.42 \\
\hline & Antiallergic & 2 & & 0.54 \\
\hline & Antiseptic & 5 & & 0.56 \\
\hline & Cut and wounds & 9 & & 0.27 \\
\hline & Scabies & 6 & & 0.62 \\
\hline & Skin diseases & 17 & & 0.54 \\
\hline \multirow[t]{3}{*}{ Faunal bite } & & & 14.00 & 0.50 \\
\hline & Insect bites & 2 & & 0.62 \\
\hline & Worms & 4 & & 0.00 \\
\hline \multirow[t]{5}{*}{ Gastrointestinal } & & & 30.20 & 0.65 \\
\hline & Gastric pain & 3 & & 0.29 \\
\hline & Liver problem & 5 & & 0.43 \\
\hline & Stomach problem & 2 & & 0.33 \\
\hline & Vomiting & 1 & & 0.00 \\
\hline \multirow[t]{13}{*}{ General health } & & & 105.00 & 0.53 \\
\hline & Bronchitis & 1 & & 0.00 \\
\hline & Cardiac tonic & 1 & & 0.00 \\
\hline & Cold ailments & 4 & & 0.50 \\
\hline & Constipation & 3 & & 0.33 \\
\hline & Diarrhea & 7 & & 0.33 \\
\hline & Dysentery & 6 & & 0.50 \\
\hline & Eye disease & 4 & & 0.40 \\
\hline & Fever & 6 & & 0.58 \\
\hline & Hair fall & 2 & & 0.46 \\
\hline & Heart disease & 1 & & 0.37 \\
\hline & Piles & 2 & & 0.56 \\
\hline & Stop bleeding & 10 & & 0.59 \\
\hline Jaundice & & 3 & 6.98 & 0.50 \\
\hline \multirow[t]{3}{*}{ Mental } & & & 6.98 & 0.33 \\
\hline & Mental depression & 1 & & 0.00 \\
\hline & Spleen disease & 2 & & 0.40 \\
\hline \multirow[t]{3}{*}{ Respiratory } & & & 25.60 & 0.60 \\
\hline & Asthma & 5 & & 0.20 \\
\hline & Cough & 6 & & 0.38 \\
\hline \multirow[t]{3}{*}{ Urinary } & & & 14.00 & 0.50 \\
\hline & Diabetes & 3 & & 0.33 \\
\hline & Urinary problem & 3 & & 0.50 \\
\hline
\end{tabular}

\footnotetext{
${ }^{\mathrm{a}}$ Sum exceeds total as in use to treat more than one category; ${ }^{\mathrm{b}}$ ICF (informant consensus factor).
} 
TABLE 3: Biological diversity indices for invasive medicinal plants status in KNP and RKWS, in Bangladesh.

\begin{tabular}{|c|c|c|c|c|c|c|c|c|}
\hline \multirow{2}{*}{ Species category } & \multicolumn{8}{|c|}{ Diversity index* } \\
\hline & $H$ & $H_{\max }$ & $E_{H}$ & SDI & $R$ & E & $D$ & $D^{\prime}$ \\
\hline Herbs & 2.75 & 2.77 & 0.99 & 0.03 & 2.35 & 2.29 & 0.1 & 0.94 \\
\hline Shrubs & 2.40 & 2.48 & 0.97 & 0.03 & 1.79 & 2.23 & 0.1 & 0.9 \\
\hline Climbers & 1.91 & 1.95 & 0.98 & 0.03 & 1.09 & 2.27 & 0.15 & 0.85 \\
\hline Grasses & 0.68 & 0.69 & 0.98 & 0.02 & 0.23 & 2.25 & 0.5 & 0.48 \\
\hline Trees & 1.76 & 1.79 & 0.98 & 0.06 & 1.08 & 2.27 & 0.18 & 0.82 \\
\hline
\end{tabular}

${ }^{*} H$ : Shannon-Wiener diversity index, $H_{\max }$ : Shannon's maximum diversity index, $E_{H}$ : Shannon's equitability index, SDI: species diversity index, $R$ : species richness index, E: species evenness index, $D$ : Simpson index, $D^{\prime}$ : dominance of Simpson index.

Cynodon dactylon (0.59), and Tectona grandis (0.24) for shrubs, climbers, grasses, and trees, respectively.

\section{Conclusion and Strategy to Utilize the Potential of Invasive Species}

In the last decade medicinal plants for healthcare have received much attention from researchers and development workers for their perceived socioeconomic importance and potential, particularly in developing countries. Though the invasive species have some detrimental impacts on ecosystem worldwide, local people living in and around the KNP and RKWS use these species as medicinal plants since time immemorial. They believe that plants are always useful for different purposes; medicinal use is one of them. This indigenous knowledge regarding invasive medicinal plants passes through from generation to generation. Our study fairly accurately represents the local healthcare practice through locally available invasive medicinal plants in the study areas. The using pattern of invasive plants documented in this paper may be helpful for other people to use these plants in their traditional healthcare practices which may minimize the pressure of using native medicinal plants.

To utilize the potential of invasive species, first potential threats of each invasive species should be identified and recorded; then develop an invasive plant strategy to minimize the long-term impacts on habitat and biodiversity. Useful invasive species can be commercially harvested in a sustainable way that does not hamper the native species plus a proper marketing channel can play important role in this case. Local community can involve in this opportunity as a worker, manager as well as buyer and seller thus they can earn money from this and would be a great scope to reduce their poverty level. The study concluded that a national programme must be initiated to increased invasive plant inventory, monitoring, research, and distinguish the harmful from the harmless plant species and to identify the use and impacts of the invasive species. As well as active government support and coordinate planning and management activities with other agencies, stakeholders are needed for the sustenance of the medicinal plants based industry in a changing global perspective and creating more awareness and introducing the medicinal plants through annual enrichment of forest plantations could positively affect the country's declining stock of such plants.

\section{Conflict of Interests}

The authors declare that they have no conflict of interests.

\section{References}

[1] T. Aburjai, M. Hudaib, R. Tayyem, M. Yousef, and M. Qishawi, "Ethnopharmacological survey of medicinal herbs in Jordan, the Ajloun Heights region," Journal of Ethnopharmacology, vol. 110, no. 2, pp. 294-304, 2007.

[2] P. K. Mukherjee and A. Wahile, "Integrated approaches towards drug development from Ayurveda and other Indian system of medicines," Journal of Ethnopharmacology, vol. 103, no. 1, pp. 25-35, 2006.

[3] R. Perumal Samy and S. Ignacimuthu, "Antibacterial activity of some folklore medicinal plants used by tribals in Western Ghats of India," Journal of Ethnopharmacology, vol. 69, no. 1, pp. 63-71, 2000.

[4] P. Revathi and T. Parimelazhagan, "Traditional knowledge on medicinal plants used by the tribe of Hasanur Hills, Erode District, Tamil Nadu, India," Ethnobotanical Leaflets, vol. 14, pp. 136-160, 2010.

[5] E. Lev, "Ethno-diversity within current ethno-pharmacology as part of Israeli traditional medicine-a review," Journal of Ethnobiology and Ethnomedicine, vol. 2, article 4, 2006.

[6] D. S. Fabricant and N. R. Farnsworth, "The value of plants used in traditional medicine for drug discovery," Environmental Health Perspectives, vol. 109, no. 1, pp. 69-75, 2001.

[7] N. R. Farnsworth and D. D. Soejarto, "Global Importance of Medicinal Plants," in The Conservation of Medicinal Plants, Cambridge University Press, Cambridge, UK, 1991.

[8] M. Karki and J. T. Williams, Priority Species of Medicinal Plants in South Asia, Medicinal and Aromatic Plants Program in Asia (MAPPA), IDRC/SARO, New Delhi, India, 1999.

[9] Z. U. Ahmed, Z. N. T. Begum, M. A. Hassan et al., Eds., Encyclopaedia of Flora and Fauna of Bangladesh [Volume 13. Angiosperms: Dicotyledons (Ranunculaceae-Zygophyllaceae)], Asiatic Society of Bangladesh, Dhaka, Bangladesh, 1st edition, 2009.

[10] The Pearl Richards Foundation, "WHO's Fact Sheet on Traditional Medicional," 2014, http://www.pearlrichards.org/theproblem.html.

[11] V. L. Feigin, "Herbal medicine in stroke: does it have a future?" Stroke, vol. 38, no. 6, pp. 1734-1736, 2007.

[12] J. A. McNeely, H. A. Mooney, L. E. Neville, P. Schei, and J. K. Waag, A Global Strategy on Invasive Alien Species, IUCN, Gland, Switzerland, 2001. 
[13] C. Shine, N. Williams, and L. Gundling, A Guide to Designing Legal and Institutional Frameworks on Alien Invasive Species, vol. 40, IUCN, Gland, Switzerland, 2000.

[14] SCBD, "Assessment and management of alien species that threaten ecosystems, habitats and species," CBD Technical Paper 1, Secretariat of the Convention on Biological Diversity, Montreal, Canada, 2001.

[15] IUCN, "The IUCN guidelines for the prevention of biodiversity loss caused by alien invasive species," in Proceedings of the 51st Meeting of the IUCN Council, International Union for Conservation of Nature, Gland, Switzerland, 2000.

[16] R. N. Mack, D. Simberloff, W. M. Lonsdale, H. Evans, M. Clout, and F. A. Bazzaz, "Biotic invasions: causes, epidemiology, global consequences, and control," Ecological Applications, vol. 10, no. 3, pp. 689-710, 2000.

[17] DAISIE, "DAISIE European Invasive Alien Species Gateway," 2010, http://www.europe-aliens.org/.

[18] D. Pimentel, S. McNair, J. Janecka et al., "Economic and environmental threats of alien plant, animal, and microbe invasions," Agriculture, Ecosystems and Environment, vol. 84, no. 1, pp. 1-20, 2001.

[19] R. Wittenberg and M. J. W. Cock, Invasive Alien Species: A Toolkit for Best Prevention and Management Practices, CABl Publishing, Wallingford, UK, 2001.

[20] H. A. Mooney and R. J. Hobbs, Invasive Species in a Changing World, Island Press, Washington DC, USA, 2000.

[21] M. A. S. A. Khan, S. Ahmed Mukul, M. Salim Uddin, M. Golam Kibria, and F. Sultana, "The use of medicinal plants in healthcare practices by Rohingya refugees in a degraded forest and conservation area of Bangladesh," International Journal of Biodiversity Science and Management, vol. 5, no. 2, pp. 76-82, 2009.

[22] M. A. S. A. Khan, F. Sultana, M. H. Rahman, B. Roy, and S. I. Anik, "Status and ethno-medicinal usage of invasive plants in traditional health care practices: a case study from northeastern Bangladesh," Journal of Forestry Research, vol. 22, no. 4, pp. 649658, 2011.

[23] IUCN, Diversity and Conservation of Wild Plants and Alien Invasive Species in Bangladesh. Concept Note on Bangladesh National Conservation Strategy and Action Plan, International Union for Conservation of Nature, Bangladesh Country Office, Dhaka, Bangladesh, 2003.

[24] M. Hossain, "Bangladesh seeks global market for its medicinal plants," 2005, http://www.scidev.net/News/index.cfm?fuseaction.

[25] M. K. Hossain and M. K. Pasha, "Alien invasive plants in Bangladesh and their impacts on the ecosystem," in Assessment and Management of Alien Species That Threatened Ecosystem: Habitats and Species, CBD Technical Paper No. 1, pp. 73-75, Secretariat of the Convention on Biological Diversity, Montreal, Canada, 2001.

[26] S. R. Biswas, J. K. Choudhury, A. Nishat, and M. M. Rahman, "Do invasive plants threaten the Sundarbans mangrove forest of Bangladesh?" Forest Ecology and Management, vol. 245, no. 1-3, pp. 1-9, 2007.

[27] M. B. Uddin, M. J. Steinbauer, A. Jentsch, S. A. Mukul, and C. Beierkuhnlein, "Do environmental attributes, disturbances and protection regimes determine the distribution of exotic plant species in Bangladesh forest ecosystem?" Forest Ecology and Management, vol. 303, no. 1, pp. 72-80, 2013.
[28] S. R. Biswas, M. S. I. Khan, and A. U. Mallik, "Invaders' control on post-disturbance succession in coastal mangroves," Journal of Plant Ecology, vol. 5, no. 2, pp. 157-166, 2012.

[29] M. P. Rana and F. Akhter, "Uses of invasive alien plant species in Rema-Kalenga Wildlife Sanctuary of Bangladesh," Journal of Mountain Science, vol. 7, no. 4, pp. 380-385, 2010.

[30] M. H. Rahman, M. A. S. A. Khan, M. J. Fardusi, and B. Roy, "Status, distribution and diversity of invasive forest undergrowth species in the tropics: a study from north-eastern Bangladesh," Journal of Forest Science, vol. 26, no. 3, pp. 149-159, 2010.

[31] M. K. Hossain, "Alien invasive plant species and their effects on hill forest ecosystems of Bangladesh," in Invasive Plants and Forest Ecosystems, R. K. Kohli, S. Jose, H. P. Singh, and D. R. Batish, Eds., pp. 133-142, CRC Press, Taylor \& Francis Group, Boca Raton, Fla, USA, 2009.

[32] A. Akter and M. I. Zuberi, "Invasive alien species in northern Bangladesh: identification, inventory and impacts," International Journal of Biodiversity and Conservation, vol. 1, no. 5, pp. 129-134, 2009.

[33] S. A. Mukul, M. B. Uddin, and M. R. Tito, "Study on the status and various uses of invasive alien plant species in and around Satchari National Park, Sylhet, Bangladesh," Tiger Paper, vol. 35, no. 4, pp. 6-9, 2008.

[34] M. I. Zuberi and A. Akter, "An account of invasive alien species (IAS) of flowering plants in Bangladesh," Plant, Environment and Development, vol. 1, no. 1, pp. 67-74, 2007.

[35] http://www.gisin.org/WebContent/WS/GISIN/Documents/ ProceedingsPDF/GISINProc2004_AppE.pdf.

[36] M. M. Islam, A. S. M. R. Amin, and S. K. Sarker, "National report on alien invasive species of Bangladesh," in Invasive Alien Species in South-Southeast Asia: National Reports and Directory of Resources, N. Pallewatta, J. K. Reaser, and A. T. Gutierrez, Eds., pp. 7-24, Global Invasive Species Programme, Cape Town, South Africa, 2003.

[37] S. R. Biswas, "Invasive plants of Sundarbans," Interim Report Under SBCP Project, IUCN Country Office, Dhaka, Bangladesh, 2003.

[38] S. P. Barua, N. M. H. Khan, and A. H. M. A. Reza, “The status of alien invasive species in Bangladesh and their impact on the ecosystems," in Alien Invasive Species-Report of Workshop on Alien Invasive Species, P. Balakrishna, Ed., pp. 1-7, IUCN Regional Biodiversity Programme of Asia, Colombo, Sri Lanka, 2001.

[39] K. R. Islam, M. Kamaluddin, M. K. Bhuiyan, and A. Badruddin, "Comparative performance of exotic and indigenous forest species for tropical semievergreen degraded forest land reforestation in Chittagong, Bangladesh," Land Degradation and Development, vol. 10, no. 3, pp. 241-249, 1999.

[40] P. Binggeli, J. B. Hall, and J. R. Healey, An Overview of Invasive Woody Plants in the Tropics, School of Agricultural and Forest Sciences, University of Wales, Bangor, UK, 1998.

[41] A. Nishat, S. Huq, M. Imamul et al., Bio-Ecological Zones of Bangladesh, IUCN Bangladesh Country Office, Dhaka, Bangladesh, 2002.

[42] M. Z. Uddin, Exploration, documentation and germplasm collection of plant genetic resources of Rema-Kalenga Wildlife Sanctuary (Habiganj) in Bangladesh [Ph.D. thesis], University of Dhaka, 2001.

[43] IRG, Site-Level Field Appraisal for Integrated Protected Area Co-Management: Khadimnagar National Park, International Resources Group (USA), Nishorgo Support Project, Bangladesh Forest Department, Dhaka, Bangladesh, 2009. 
[44] R. S. Shukla and P. S. Chandel, Plant Ecology and Soil Science, S. Chand and Company, Ramnagor, New Delhi, India, 9th edition, 2000.

[45] R. S. Ambasht, A Textbook of Plant Ecology, Students Friends and Co., Lanka, Varanasi, India, 1979.

[46] T. K. Dey, Useful Plants of Bangladesh, The Ad Communication, Chittagong, Bangladesh, 2nd edition, 2006.

[47] USDA/ARS/GRIN, "National Genetic Resources Program online database," 2010, http://plants.usda.gov/.

[48] Z. U. Ahmed, M. A. Hassan, Z. N. T. Begum et al., Eds., Encyclopaedia of Flora and Fauna of Bangladesh [Volume 6. Angiosperms: Dicotyledons (Acanthaceae-Asteraceae)], Asiatic Society of Bangladesh, Dhaka, Bangladesh, 2008.

[49] R. S. M. Karim and H. M. Kabir, Introduction to Weeds of Bangladesh (in Bengali), Bangla Academy, Dhaka, Bangladesh, 1995.

[50] A. K. M. N. Islam, Two Centuries of Plant Studies in Bangladesh and Adjacent Regions, Asiatic Society of Bangladesh, Dhaka, Bangladesh, 1991.

[51] K. U. Siddique, M. A. Islam, Z. U. Ahmed et al., Eds., Encyclopaedia of Flora and Fauna of Bangladesh [Volume 11, Angiosperms: Monocotyledons (Agavaceae-Najadaceae)], Asiatic Society of Bangladesh, Dhaka, Bangladesh, 2007.

[52] P. Raizada, "Invasive Species: the Concept, invasion process, and impact and management of invaders," Archives of Environment News -Newsletter of ISED India, vol. 13, no. 3, pp. 12-15, 2007.

[53] C. Wilson, Parks and Wildlife, Parks and Wildlife Commission of the Northern Territory, Palmerston, Australia, 2006.

[54] K. U. Siddique, M. A. Islam, Z. U. Ahmed et al., Eds., Encyclopaedia of Flora and Fauna of Bangladesh [Volume 5, Bryophytes, Pteridophytes, Gymnosperm], Asiatic Society of Bangladesh, Dhaka, Bangladesh, 2008.

[55] Z. U. Ahmed, M. A. Hassan, Z. N. T. Begum et al., Eds., Encyclopaedia of Flora and Fauna of Bangladesh [Volume 7. Angiosperms: Dicotyledons (Balsaminaceae-Euphorbiaceae)], Asiatic Society of Bangladesh, Dhaka, Bangladesh, 2008.

[56] M. Costea, G. L. Nesom, and S. Stefanović, "Taxonomy of the cuscuta pentagona complex (Convolvulaceae) in North America," SIDA, Contributions to Botany, vol. 22, no. 1, pp. 151175, 2006.

[57] M. Wardah and M. Bink, "Bryophyllum," in Plant Resources of South East Asia 12(1) Medicinal and Poisonous Planta 1, L. S. de Padua, N. Bunyapraphatsara, and R. H. M. J. Lemmens, Eds., Backhuys, Leiden, the Netherlands, 1999.

[58] M. M. Mirza and M. Rahman, "An annotated checklist of ferns and fern-allies of Bangladesh," Bangladesh Journal of Plant Taxonomy, vol. 4, no. 2, pp. 47-69, 1997.

[59] Z. U. Ahmed, M. A. Hassan, Z. N. T. Begum et al., Eds., Encyclopaedia of Flora and Fauna of Bangladesh [Volume 8. Angiosperms: Dicotyledons (Fabaceae-Lythraceae)], Asiatic Society of Bangladesh, Dhaka, Bangladesh, 2009.

[60] Z. U. Ahmed, M. A. Hassan, Z. N. T. Begum et al., Eds., Encyclopaedia of Flora and Fauna of Bangladesh [Volume 9. Angiosperms: Dicotyledons (Magnoliaceae-Ponicaceae)], Asiatic Society of Bangladesh, Dhaka, Bangladesh, 2009.

[61] Z. U. Ahmed, M. A. Hassan, Z. N. T. Begum et al., Eds., Encyclopaedia of Flora and Fauna of Bangladesh [Volume 12. Angiosperms: Monocotyledons (Orchidaceae-Zingiberaceae)], Asiatic Society of Bangladesh, Dhaka, Bangladesh, 2008.

[62] R. P. Wunderlin, B. F. Hansen, and E. L. Bridges, Atlas of the Flora of Florida, Tampa [CD-ROM], Florida Department of State, Tampa, Fla, USA, 1996.
[63] L. Brouillet, F. Coursol, and M. Favreau, "VASCAN", the Database of Canadian Vascular Plants, Canada, 2006.

[64] Z. U. Ahmed, M. A. Hassan, Z. N. T. Begum et al., Eds., Encyclopaedia of Flora and Fauna of Bangladesh [Volume 10. Angiosperms: Dicotyledons (Ranunculaceae-Zygophyllaceae)], Asiatic Society of Bangladesh, Dhaka, Bangladesh, 2010.

[65] R. Trotter and M. Logan, "Informant consensus: new approach for identifying potentially effective medicinal plants," in Indigenous Medicine and Diet: Behavioural Approaches, N. L. Etkin, Ed., pp. 91-112, Redgrave Publishers, New York, NY, USA, 1986.

[66] M. Hudaib, M. Mohammad, Y. Bustanji et al., "Ethnopharmacological survey of medicinal plants in Jordan, Mujib Nature Reserve and surrounding area," Journal of Ethnopharmacology, vol. 120, no. 1, pp. 63-71, 2008.

[67] E. P. Odum, Fundamentals of Ecology, W. B. Saunders, Philadelphia, Pa, USA, 1971.

[68] R. Margalef, "Temporal succession and spatial heterogeneity in phytoplankton," in Perspective in Marine Biology, A. A. T. Buzzati, Ed., p. 470, University of California Press, Berkeley, Calif, USA, 1958.

[69] P. Michael, Ecological Methods for Field and Laboratory Investigation, Tata McGraw Hill, New Delhi, India, 1990.

[70] M. Kent and P. Coker, Vegetation Description and Analysis: A Practical Approach, Belhaven Press, London, UK, 1992.

[71] E. C. Pielou, Ecological Diversity, Wiley InterScience, New York, NY, USA, 1975.

[72] A. E. Magurran, Ecological Diversity and Measurement, Princeton University Press, Princeton, NJ, USA, 1988.

[73] R. M. May, "Patterns of species abundance and diversity," in Ecology and Evolution of Communities, M. Cody and J. Diamond, Eds., Harvard University Press, Cambridge, Mass, USA, 1975.

[74] S. A. Mori, B. M. Boom, A. M. Carvalino, and D. Santos, "The ecological importance of Myrtaceae in eastern Brazilian wet forest," Biotropica, vol. 15, pp. 68-70, 1983.

[75] M. H. Rahman, M. J. Uddin, and M. B. Uddin, Integrating Hill Farming with Livelihood and Forest Conservation: Field Experience from Ethnic Communities Living in and around Lawachara National Park, Bangladesh, LAP LAMBERT Academic Publishing, AV Akademikerverlag GmbH and Co. KG, Saarbrücken, Germany, 2012.

[76] M. H. Rahman and M. J. Fardusi, "Indigenous plant utilization and farming system of garo tribe in north-east bangladesh: a means of sustainable biodiversity conservation," Journal of Forest Science, vol. 28, no. 2, pp. 84-96, 2012.

[77] H. Rahman, M. Rahman, M. Islam, and S. Reza, "The importance of forests to protect medicinal plants: a case study of Khadimnagar National Park, Bangladesh," International Journal of Biodiversity Science, Ecosystems Services and Management, vol. 7, no. 4, pp. 283-294, 2011.

[78] M. H. Rahman, M. J. Fardusi, and M. S. Reza, “Traditional knowledge and use of medicinal plants by the Patra tribe community in the North-Eastern region of Bangladesh," Proceedings of the Pakistan Academy of Sciences, vol. 48, no. 3, pp. 159-167, 2011.

[79] M. H. Rahman, M. Rahman, B. Roy, and M. J. Fardusi, "Topographical distribution, status and traditional uses of medicinal plants in a tropical forest ecosystem of Northeastern Bangladesh," International Journal of Forest Usufructs Management, vol. 12, no. 1, pp. 37-56, 2011. 
[80] M. S. H. Chowdhury and M. Koike, "Therapeutic use of plants by local communities in and around Rema-Kalenga Wildlife Sanctuary: implications for protected area management in Bangladesh," Agroforestry Systems, vol. 80, no. 2, pp. 241-257, 2010.

[81] M. S. H. Chowdhury and M. Koike, "Towards exploration of plant-based ethno-medicinal knowledge of rural community: basis for biodiversity conservation in Bangladesh," New Forests, vol. 40, no. 2, pp. 243-260, 2010.

[82] M. P. Rana, M. S. I. Sohel, S. Akhter, and M. J. Islam, "Ethnomedicinal plants use by the Manipuri tribal community in Bangladesh," Journal of Forestry Research, vol. 21, no. 1, pp. 8592, 2010.

[83] M. P. Rana, M. S. I. Sohel, S. Akhter, and M. R. Hassan, “The use of plants in indigenous health care practice of the hajong tribe community in North Eastern Bangladesh," Journal of Forest Science, vol. 25, no. 1, pp. 25-33, 2009.

[84] S. A. Mukul, M. B. Uddin, and M. R. Tito, "Medicinal plant diversity and local healthcare among the people living in and around a conservation area of Northern Bangladesh," International Journal of Forest Usufructs Management, vol. 8, no. 2, pp. 50-63, 2007.

[85] M. D. Miah and M. S. H. Chowdhury, "Indigenous healthcare practice through medicinal plants from forest by the Mro tribe in Bandarban region, Bangladesh," INDILINGA: African Journal of Indigenous Knowledge System, vol. 2, pp. 61-73, 2003.

[86] GISP, Tropical Asia Invaded: The Growing Danger of Invasive Alien Species, The Global Invasive Species Programme, 2004.

[87] M. Heinrich, "Ethnobotany and its role in drug development," Phytothera Research, vol. 14, no. 7, pp. 479-488, 2000.

[88] B. O. Owuor and D. P. Kisangau, "Kenyan medicinal plants used as antivenin: a comparison of plant usage," Journal of Ethnobiology and Ethnomedicine, vol. 2, article 7, 2006.

[89] S. Ragupathy, N. G. Steven, M. Maruthakkutti, B. Velusamy, and M. M. Ul-Huda, "Consensus of the "Malasars" traditional aboriginal knowledge of medicinal plants in the Velliangiri holy hills, India," Journal of Ethnobiology and Ethnomedicine, vol. 4, article 8, 2008.

[90] H. Yineger, E. Kelbessa, T. Bekele, and E. Lulekal, "Plants used in traditional management of human ailments as Bale Mountains National Park, Southeastern Ethiopia," Journal of Medicinal Plants Research, vol. 2, no. 6, pp. 132-153, 2008.

[91] M. H. Rahman, M. A. S. A. Khan, B. Roy, and M. J. Fardusi, "Assessment of natural regeneration status and diversity of tree species in the biodiversity conservation areas of Northeastern Bangladesh," Journal of Forestry Research, vol. 22, no. 4, pp. 551559, 2011.

[92] M. L. Rahman, M. K. Hossain, and Q. M. N. Karim, "Diversity and composition of tree species in Chunati Wildlife Sanctuary of Chittagong Forest Division, Bangladesh," The Chittagong University Journal of Science, vol. 24, no. 1, pp. 89-97, 2000.

[93] N. Top, N. Mizoue, S. Ito, S. Kai, T. Nakao, and S. Ty, "Effects of population density on forest structure and species richness and diversity of trees in Kampong Thom Province, Cambodia," Biodiversity and Conservation, vol. 18, no. 3, pp. 717-738, 2009. 

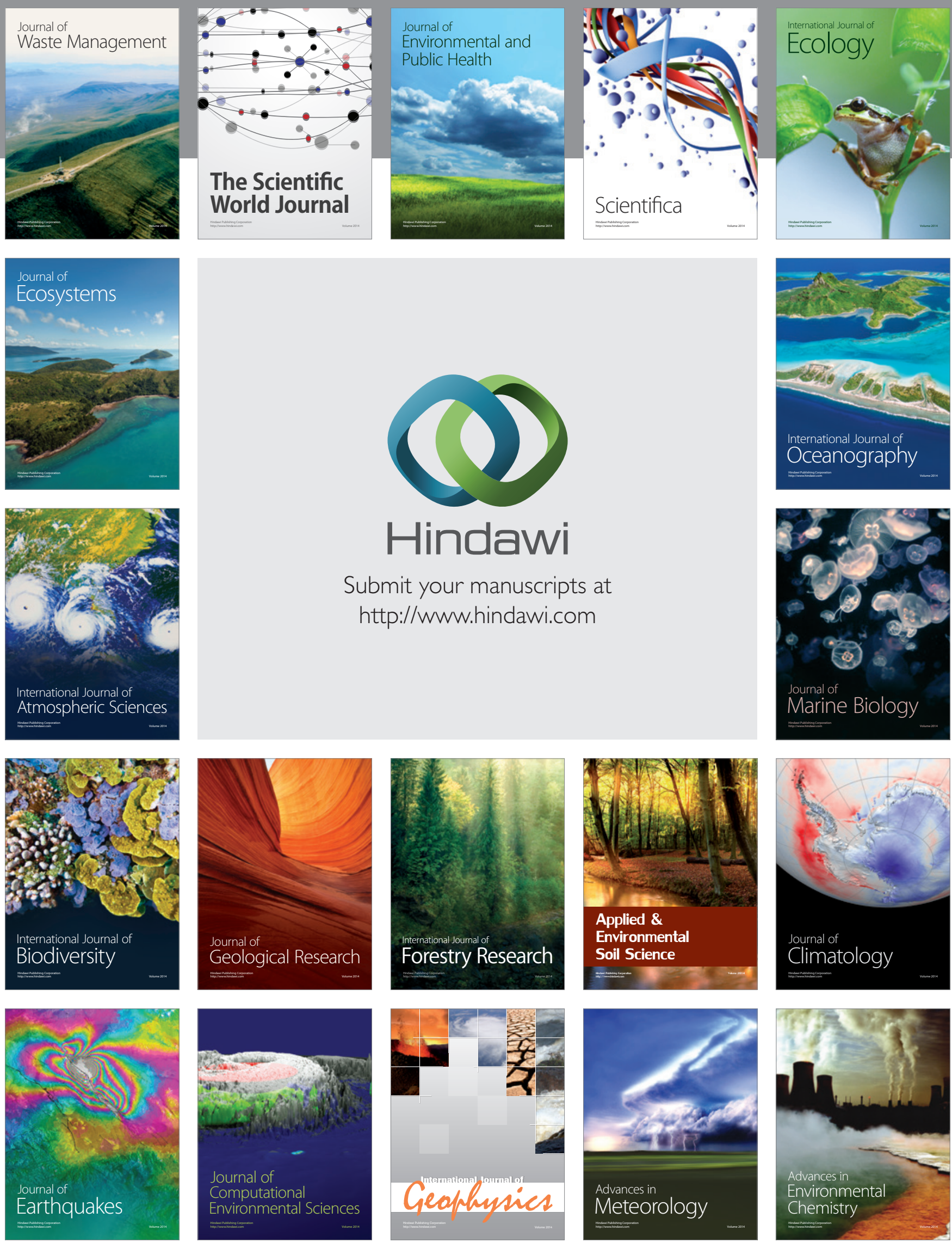